術前白血球数減少をきたした穿孔性腹膜炎症例の検討

\author{
川崎医科大学救急医学 \\ 化雅良藤井千穂
}

過去10年間汇当施設で手術・治療した穿孔性腹膜炎症例170例のらち，術前に白血球数 か5 $5,000 / \mu 1$ 以下に減少していた症例は24例であった，白血球数減少は，高龄者および大 渴穿孔灶多かった。白血球数减少例では術後に白血球数は增加しており，術後2日目ま では幼弱好中球が增加し，その後成熟好中球が增加していた。

白血球数減少例の死亡率は $12.5 \%$ で，非减少例と統計上の有意盖はなかった。しかし 来院時に血圧の低下した症例では27.3\%の死亡であるのに対し，血王低下のないるので

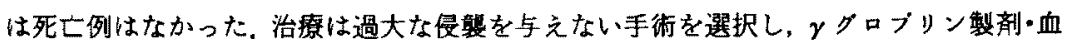

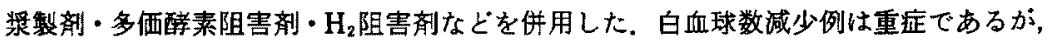
適切な治療により救命しらると考えられる。

卖引用語：白血球数减少，穿孔性腹膜炎

\section{緒 言}

穿孔性腹膜炎に扎いては，年齢・穿孔部位・穿孔後 時間・ショックの存在板どとともに白血球数の減少が risk factor として指摘されている゙.しかし，手術前に すでに白血球が诚少している症例についての詳紐な報 告は少ない，今回われわれは，術前に白血球数减少を きたした穿孔性腹膜炎症例について検討したので報告 する.

\section{対象と方法}

1981年 1月から1990年12月までの10年間に当科で手 㭪した穿孔性腹膜炎症例は170例であり，男性128例女 性42例，年路は 4 歳から90歳まで平均 47.8 歳，死亡は 16例であった。

このうち涌前の白血球数が $5,000 / \mu 1$ 以下であった 症例（以下白血球数减少例）は24例であった，男性11 例女性13例，平均年龄68.1歳，死亡は 3 例であった。 これらの症例について retrospectiveに检討を加之 た.

$$
\text { 結 果 }
$$

\section{1. 穿孔部位}

穿孔部位と白血球数減少例の出現頻度を表 1 に示 士。大腸穿孔23例（小腸との合併穿孔 2 例を含む）の 5ち12例 $(52.2 \%)$ 之，大腸穿孔での頻度が正椡的に 高い。

1991年 4 月12日受付 1991 年12月 4 日採用

\section{表 1 穿孔部位による衍前白血球数減少例数}

\begin{tabular}{|c|c|c|}
\hline & 全应例数 & 街前泉血球 \\
\hline 胃 & $11(3)$ & 1 \\
\hline 十二指晹 & $54(5)$ & 7 \\
\hline 署十小腸 & 1 & 0 \\
\hline 小啲 & $35(5)$ & $2(1)$ \\
\hline 虫垂 & 46 & 2 \\
\hline 小腸十大践 & 2 & 0 \\
\hline 大朆 & $21(3)$ & $12(2)$ \\
\hline 合 計 & $170(16)$ & $24(3)$ \\
\hline
\end{tabular}

\section{2. 年秢}

170例においてて，年龄と来院時の白血球数の関係を图 1のタララフに示した，年秢が高くなるほど白血球数は 少ない傾向にある，白血球数减少例は 1 例（14歳）を 除いて49歳以上であった。これは穿孔部位別に検討し ても同様の傾向であった。

\section{3. 穿孔後の時間}

穿孔後の時間と白血球数の関保を图 2 のクラフに示 した，両者の間には，顕著な関係は，認められない。 しかし，穿孔部位別にみると，大腸穿孔では24時間以 内に過半数が $5,000 / \mu 1$ 以下に減少している（図3).

\section{4. 腹水培}

開腹時124例に腹水培羡を行った。その結果を表 2 に 示す，白血球数減少例に怙いて細菌が検出されなかっ 


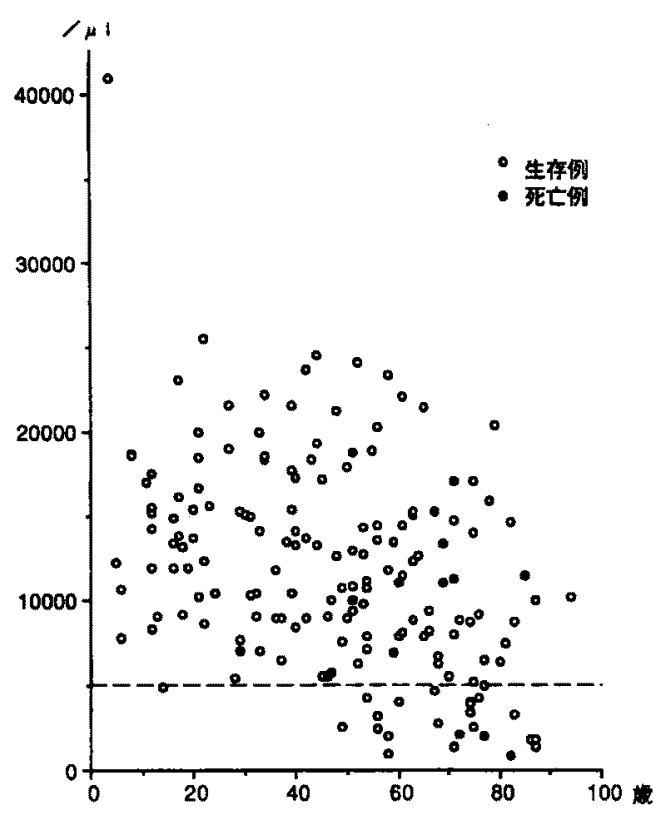

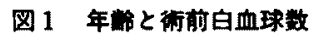

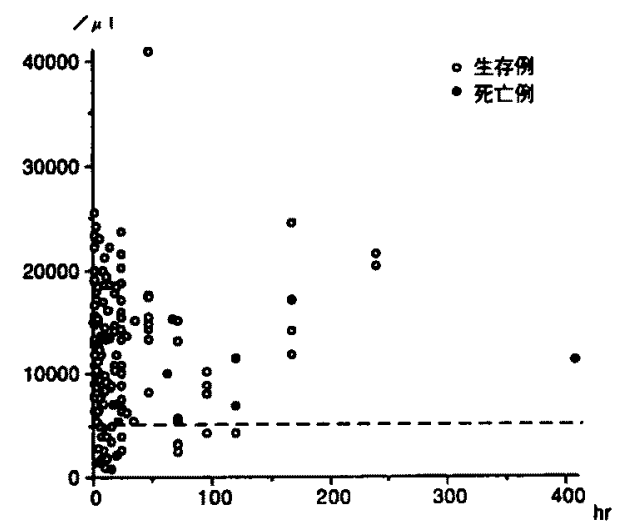

图 2 穿孔後時间と白血球数

たのは 1 例(4.8\%)だけであり，103例中18例(17.5\%) の非減少例飞比へて細菌陽性例が多かった，またいず れにおいてす視数菌の検出例がみられるが，その平均 菌種数は，非減少例で2.28，減少例で2.95であり減少 例の方が䙓数菌の傾向が强かった。

菌種をるる，減少例で非減少例にくらへ Klebsiella, E. faecalis, Enterobacter などの検出率が高 かった.

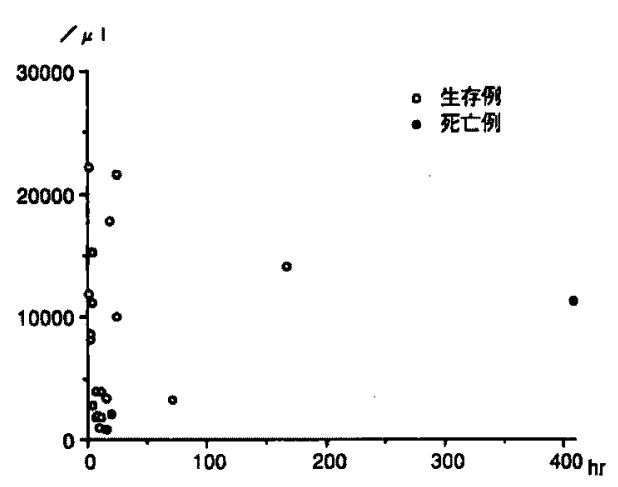

图 3 大衶穿孔の穿孔後時间と術前白血球数

\section{衰 2 服水培盖の桔果}

\begin{tabular}{|c|c|c|c|}
\hline & 計 & 非減少例 & 减少例 \\
\hline 症例数 & 124 & 103 & 21 \\
\hline 娭出されず & 19 & 18 & 1 \\
\hline \multicolumn{4}{|l|}{ 恰出菌 } \\
\hline E. coli & 58 & 47 & 11 \\
\hline Bacteroides & 45 & 38 & 7 \\
\hline Klebsiella & 35 & 23 & 12 \\
\hline Streptococcus & 23 & 17 & 6 \\
\hline Pseudomonas & 16 & 15 & 1 \\
\hline E. faecalis & 14 & 10 & 4 \\
\hline Proteus & 12 & 11 & 1 \\
\hline Enterobacter & 9 & 6 & 3 \\
\hline Lactobacillus & 6 & 6 & 0 \\
\hline その他 & 33 & 23 & 14 \\
\hline
\end{tabular}

\section{5. 術啳の推移}

次に術前白血球减少例に扰いて白血球の数, 分画に ついて検討した。

白血球数の推移をみると，術前は平均 $2,947 / \mu 1$, 術 後第 1 病 日6.332/ $\mu 1$, 第 2 病 $89.466 / \mu 1$, 第 3 病日 $9,742 / \mu \mathrm{l}$ と順調に增加していた(図 4).この須向は生 存例と死亡例では差がなかった。

白血球の分画をみる之，幼弱好中球（好中球のらち 分葉核球以外の桿状球 band granulocyte・後骨䯣球 metamyelocyte・骨蹎球 myelo cyte などの総計)は得 前1,505/ $\mu 1(47.5 \%)$ ，㭪後第 1 病日 $3.819 / \mu 1(58.4 \%)$, 第 2 病 日3,805/ $\mu 1(41.8 \%)$, 第 3 病 日 $2,263 / \mu 1$ (23.2\%)といったん増加しその後減少していた，一方 成熟好中球（分葉核球 segment granulocyte）は術前 $811 / \mu 1(30 \%)$ ，術後第 1 病日1,819/ $\mu 1(26.3 \%)$, 第 2 病日 $4,213 / \mu 1(48.5 \%)$, 第 3 病日 $6.748(67.4 \%)$ 


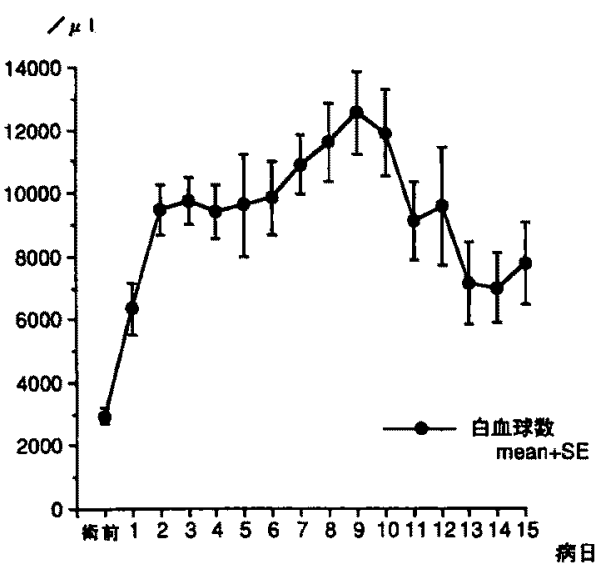

图 4 白血球数の推䅂（術前白血球数減少例）
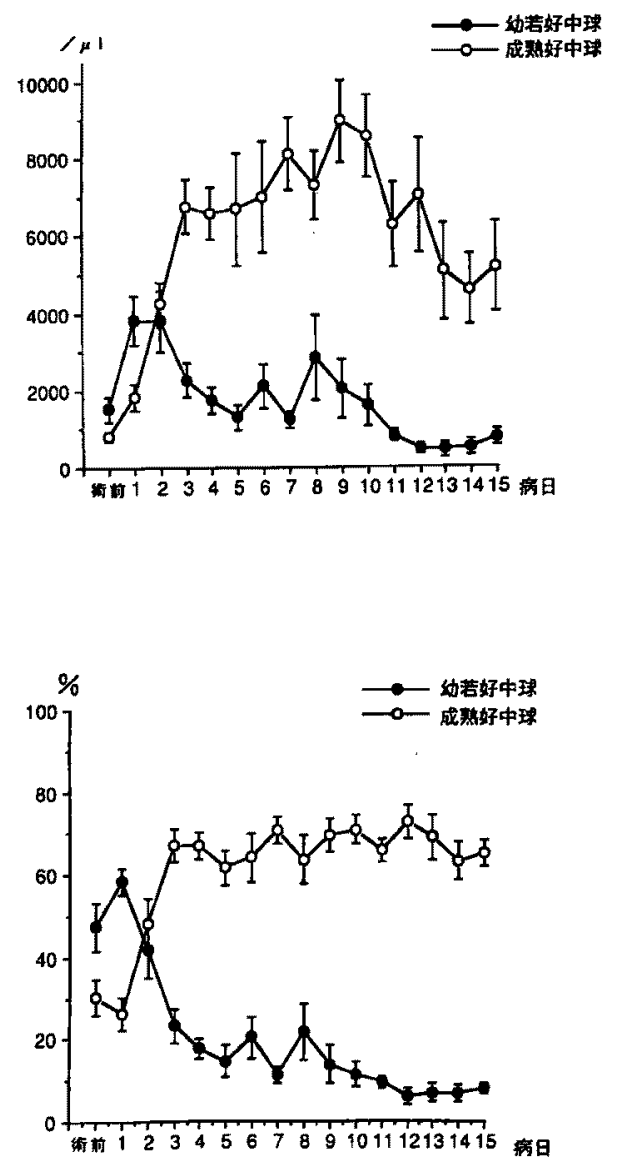

图 5 幼若好中球と成熱好中球の数 (上段)と比率（下 段）の推移（很前白血球数減少例）

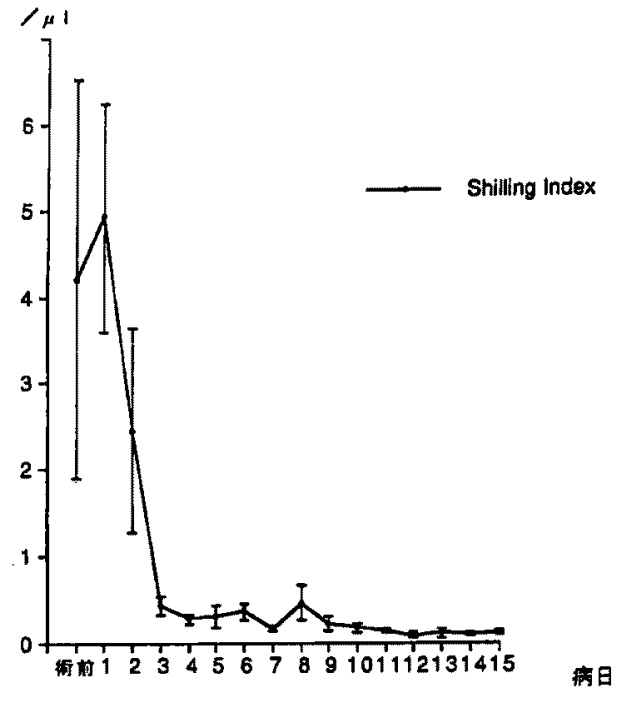

图 6 Shilling Index の推移

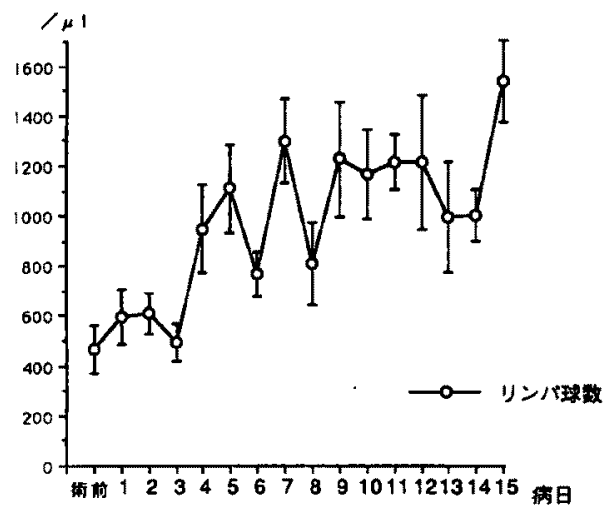

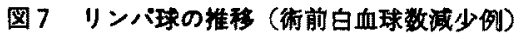

と堌加していた（図 5)，両者は第 2 病日に交攴してい た，この結果，Shilling Index（奻若好中球/成熱好中 球)は第 1 病日に平均 4.92 となり，第 3 病日以降は1.0 以下となった（图6).

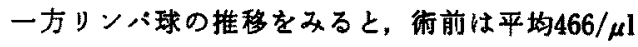
で, 術後第 4 病日から增加していた（图７）。

\section{6. 合侀症}

白血球数減少例における衍前合併拝は11例にみら 九，高血圧 5 例，脳梗塞 1 例，僈性撉不全（透析中） 2 例，䊰尿病 1 例，慢性肝资 1 例，慢性関節リウマチ 1 例，再生不良性負血 1 例などですった，また喉頭癌 
表 3 白血球娍少と死亡年

\begin{tabular}{|c|c|c|c|}
\hline & 生存例 & 死亡例 & 計 \\
\hline 衍前白血球繁 & 133 & $13(12.5 \%)$ & 146 \\
\hline \multirow[t]{2}{*}{ 减少例 } & 21 & $3(8.9 \%)$ & 24 \\
\hline & 154 & 16 & 170 \\
\hline
\end{tabular}

表 4 血圧低下の有無と死亡率の成保

\begin{tabular}{|c|c|c|c|}
\hline & 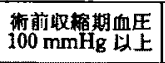 & $100 \mathrm{mmHg}$ & 竐 \\
\hline 術前泉血珑繁 & $7.0 \%(8 / 114)$ & $15.6 \%(5 / 32)$ & $8.9 \%(13 / 146)$ \\
\hline 同 减少例 & $0 \%(0 / 13)$ & $27.3 \%(3 / 11)$ & $12.5 \%(3 / 24)$ \\
\hline 就 & $6.3 \%(8 / 127)$ & $18.6 \%((8 / 43)$ & $9.4 \%(16 / 170)$ \\
\hline
\end{tabular}

のため唉頭摘出後の 1 例が抗睡場薬 Krestin を服用中 であった。

24例中17例になんらかの術後合併症を認めた. DIC 敗血庭性ショックが各 5 例，腹腔内膿赛，消化管出血， 急性膵炎がそれぞれ 3 例で，その他心不全，肺资，1 レゥスなとであった。

\section{7. 死亡率}

白血球数減少例上非減少例において死亡率を比較す ると(表 3)，减少例の $12.5 \%$ に対し非减少例では8.9\% であり， $x^{2}$ 愉定で両者に有意差を認めなかった $\left(x^{2}=\right.$ $0.313, \mathrm{p}>0.05)$.

\section{8. 来院時血在}

白血球数減少例と非減少例において，来院時の取縮 期血压が $100 \mathrm{mmHg}$ 以上と $100 \mathrm{mmHg}$ 末满に分けて予 後をみた(表 4 )。非減少例では両者閒に有意差はみら れなかった。しかし，減少例では血压の低下した症例 の死亡率が27.3\%であるのに対し，血任低下のないも のでは死亡例はなかった。

\section{9. 治療}

白血球減少例における治療法を表 5 にをとめた。図 2，3に示すように穿孔後24時間以上を経て紹介され てくる症例も多いため，胃・十二指腸穿孔においては 大網充填 - 大絧包埋淿管法，大腸に和いても人工肛門 造設街なと，できるだけ侵較の少ない手術を選択して いる，また多くの症例で $\gamma$ クロブリン製剤，新鮮凍結

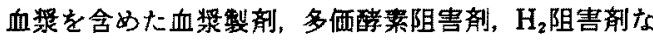

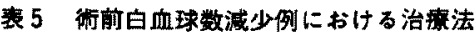

\begin{tabular}{|c|c|c|c|}
\hline 手埜 & . & & \\
\hline \multirow[t]{3}{*}{ 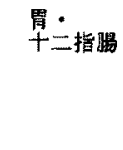 } & 8例 & 琴切路術 & 3例 \\
\hline & & 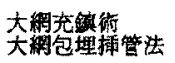 & 4例 \\
\hline & & 穿孔部叠合 & 1例 \\
\hline 小睗 & 2例 & 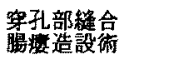 & 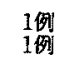 \\
\hline 虫垂 & 2 例 & $\begin{array}{l}\text { 虫垂切除術 } \\
+ \text { ドレナーシ }\end{array}$ & 2例 \\
\hline 大朅 & 12例 & 人工肛門造設街 & 12例 \\
\hline \multicolumn{4}{|c|}{ その他の治撚 } \\
\hline \multicolumn{2}{|c|}{ ガンマタロブリン製戍 } & 15例 & \\
\hline \multicolumn{2}{|c|}{ 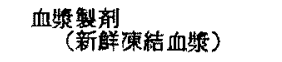 } & $\begin{array}{l}24 \text { 例 } \\
20 \text { 例. }\end{array}$ & \\
\hline \multicolumn{2}{|c|}{$\begin{array}{l}\text { メン酸がベキサート } \\
\text { またはウリナスタチン }\end{array}$} & 22 例 & \\
\hline \multicolumn{2}{|c|}{$\mathrm{H}_{2}$ プロッカー } & 19例 & \\
\hline
\end{tabular}

どを併用している。

\section{考察}

穿孔性腹膜炎においては，年龄・穿孔部位・穿孔绕 時間・ショックの存在などとともに術前白血球数の隇 少が risk factor として指摘されている゙。しかしこ の衍前白血球数减少例についての詳細な報告は少な い、合回我々は，游前に白血球数娍少をきたした穿孔 性腹膜炎症例について検討した。

白血球数減少例としては，4,000/ $\mathrm{l}$ 以下上する報

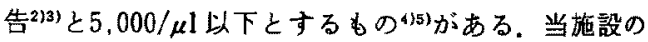
白血球数の正常值は正常值は3,500 8.500/ $\mu 1$ である が，呀孔性腹膜炎では，白血球が增加することが正常 の反応であることから、我々は5,000/ $\mu 1$ 以下を減少例 として検討を加えた。

部位別にみると, 白血球数減少例は大腸に王倒的に

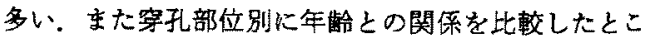
ろ，年略が高くなるほど白血球は減少する㑯向にあっ た，次に穿孔後の時間と白血球の関俰をみると，穿孔 後の時間が長い性と減少するといらよらな関係はみら れなかった，特に大腸穿孔では穿孔後24時間以内に白 血球数が減少する庭例が多く，他の部位之大きく異 なっていた。

開䧗時の腹水培养の検討では，減少例に扣いて細菌 陽性例が多く，複数菌として検出される定例が多いと の㑯向が認められた。菌種では, Klebsiella が減少例で $60 \%$ (非減少例で26.7\%) と最も多く検出された。 し たがって Klebsiellaが白血球減少に大きく関与して

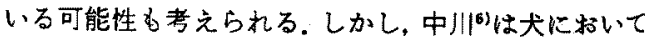


E. coli と Pseudomonas aeruginosa を用いて穿孔性 腹膜炎を作成し，白血球の減少を報告している，姝気 性菌やグラム陰性桿菌などの梅数菌感染が白血球を消 費すると考克られる。な挆減少例は大腸穿孔が多いに わかかからず, E. coli, Bacteroides の頻度が非隇少例 と差がないのは，蝶穿孔例でこの 2 種が娭出されて いた影筫である。

白血球数減少例の術後の白血球数の推移をみると， 白血数は第 1 病日から順調に增加していた。岸本 ら ${ }^{5}$ 恃白血球数减少例を，さらに韦後白血球が増加し た群と減少したままの群に分けて，減少したままの群 では死亡率が高いと報告している、しかし，われわれ の検討では生存例と死亡例は同じバターンで增加して いた，また白血球の分画をみると，幼弱好中球はい。 たん増加して隇少し，成㠇好中球は術後增加して，両 者は第 2 病日に交叉していた。

白血球が減少する原因は，敗血症の上る骨面の抑制 であるといわれている677。 しかし，自験例の経過から 白血球数か減少しても幼弱好中球住增加しているこ と，手術後すぐ焻血球数は增加してくること，その 增加にともなって成熟好中球の比率が增加してくるこ となどから，白血球の生産は排制されていないと考元 られる。すなわち，白血球数减少の原因は骨噵の抑制 ではなく，消費が増加したためと考えられる。中川゙は 犬に护ける腹膜炎作成実駼に打いて末梢血白血球が減 少し，腹木中の白血球数が増加したことを報告してお り，白血球が腹腔内に動員されることを示唆している。 白血球数减少の原因について，今後さらに険討を加之 たい.

また白血球の减少は敗血症性ショックにともなって おこるといわれている37788. しかし，自験例では24例中 13例は術前收樎期血王 $100 \mathrm{mmHg}$ 以上であり，血王低 下上りる白血球数减少の方が先におこる可能性が高い と思われた。ささらに術前収縮期血压 $100 \mathrm{mmHg}$ 以上の 白血球数减少例では死亡例はなく，敗血症性ショック に陥る前に治療を開始することが非常に重要であるこ とを示している。

白血球数减少に伴って好中球ととむにリン八球む減

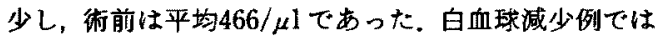
稩胞性免疫能が高度に低下寸ることが示された。リン ：球の增加は好中球にやや㩧九，第 4 病日ごろからて ある。これはリンバ球の生成が好中球よりる遗いため と思われる。われわれ摡に重症熱傷患者において。 末梢リンパ球数が $1,000 / \mu 1$ 以下に低下した症例では

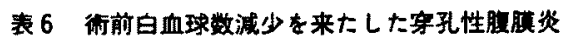
症例の報告

\begin{tabular}{c|c|c|c|c|c}
\hline 年 & 報告者 & 白血球数 & 店例 & 死亡数 & 死亡率 \\
\hline 1986 & 竹内ら & $5,000 / \mu 1$ 以下 & 16 & 7 & $43.8 \%$ \\
1987 & 里島ら & $4,000 / \mu 1$ 以下 & 19 & 10 & $52.8 \%$ \\
1988 & 松田ら & $4,000 / \mu 1$ 以下 & 14 & 6 & $42.9 \%$ \\
1990 & 岸本ら & $5,000 / \mu 1$ 以下 & 25 & 8 & $32.0 \%$ \\
1991 & 自験例 & $5,000 / \mu 1$ 以下 & 24 & 3 & $12.5 \%$ \\
& & $4,000 / \mu 1$ 以下 & 18 & 2 & $11.1 \%$ \\
\hline
\end{tabular}

死亡率が高いことを報告した99. 今回の検討での減少 例は術後 1 $1,000 / \mu 1$ 以下の状態か続くが, 死亡率は高 くない。これは創面からの細菌侵入が続く熱倁と，手 術後は細菌の污染が止まる穿孔との違いによると思わ れる。

白血球数减少例は非減少例に比べて死亡率が高いこ とが報告されている21-5)（表6）。これまでの報告はい， ずれも30\%以上の高い死亡率である．しかし自験例で は5,000/ $\mu 1$ 以下で $12.5 \%, 4,000 / \mu 1$ 以下で11.1\%であ り，非减少例と比へて死亡率の有意差はなかった。

われわれは治療上して，できるだけ早く(大腸では 少なくとも6 時間以内）開腹術を施行し，腹腔内性 $100 \sim 200 \mathrm{ml} / \mathrm{kg}$ を目安として早温生理食塩水が清澄 になるまで徹底的な洗浄を行い，表5に示したよらに できるたけ過大な侵劕を加えない㭪式を採用してい

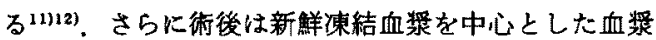

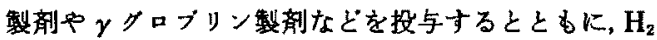
阻害剂与併用し消化管出血を予防している.

当施設での白血球数減少例の死亡率が他の報告者よ りむ低い原因は明らかではないか，このような治療方 針や，很前後の集中治療・抗生剂などの䔔切な使用が その要因と考兄られる。松田ら゙はわれわれと同様に,

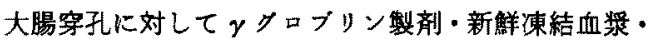
H2阻害剤などを併用した集中治療を施行し，救命率が 向上したことを報告している，術前白血球数の减少例 は重症であるが，早期に適切な手術を施行し，術後に 集中治療を行らことにより，死亡率を改善しらると考 えられる．白血球数减少例は免度能が低下し，重应で あるという認識がもっとも重要である。

$$
\text { 結 語 }
$$

術前白血球数減少をきたした穿孔性腹膜炎症例24例 について検討した，術前白血球数减少は，高龄者・大 陽第孔に起こることが多い.術前白血球数减少例では， 術後に白血球数は堌加し，最初恃幼弱好中球吕，つ小 
で成熟好中球が増加していた，術前白血球数減少例の 死亡率は12.5\%であった，術前白血球数減少例は重症 であるか゚，早期に適切な手術を施行し，術後に集中治 薏を行らことにより，救㧱の道が開けると考えられた。 文暗

1）木户訓一，鈴木幸一郎，田中茂地：穿孔性腹膜桨 の手術方猃上術前・術後管理，放急医 8：687 $-695,1984$

2）黒島一直，寺田 宰，产孝他：いわゆる特発性

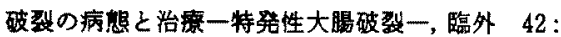
$343-348,1987$

3）松田昌三，福岡弘晃，山本英博他：大隅穿孔性腹膜 资人対する術前上りの抗ショック療法の有圽性， 搌部救急影暴の進步 8:899-904, 1988

4）竹内䓃司, 小長英二，川真田他：下部消化管穿孔 の検討，日臨外医会敔 $47: 581-587,1986$

5）岸本康朗，中尾量保，前田克昭他：穿孔性腹膜资に おけける leukocytopenia の重䈍度上街後凌器障害, 日消外会誌 $23: 1561,1990$
6）中川隆雄：急性腹膜炎に打ける好中球 NBT 溉元 能に间する研究，特に $\gamma$ クロブリン投与と全身低 体温の好果について一，東京女医大倍 50：191 $-207,1980$

7)松萎敬夫, 福留 厚, 松尾 総他: 非外傮性大晹穿 孔について，外科彭療 $24: 721-728,1982$

8）三村一夫，高楯 裕，平出星夫他：大腸穿孔，僌急 医 $8: 707-714,1984$

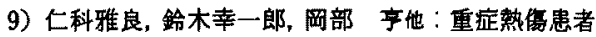
に括ける末梢りンパ球数の意義。第 13 回敉急医学 会抄録, pl58, 1985

10）合光秀榣，花野祥子，益田美也子他：下部消化管穿 孔一初期治療としての腹腔内大量洗浄を中心に 一，敉急医 5:499-504, 1981

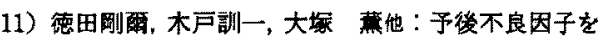

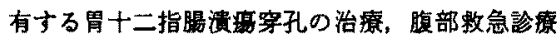
の進歩 6:739-743, 1986

12）北科雅良，藤井千穗，福西克之他：特発性大腸穿孔 の検討，外科 $50: 282-285,1988$

\title{
A CLINICAL STUDY OF PERFORATIVE PERITONITIS PRESENTING WITH LEUKOCYTOPENIA PREOPREATIVELY
}

\author{
Masayoshi NISHINA and Chiiho FUJII \\ Department of Acute Medicine, Kawasaki Medical School
}

In 170 cases of perforative peritonitis surgically treated at the institution during the past one decade, 24 cases were preoperatively associated with leukocytopenia of less than $5,000 / \mathrm{mm}^{3}$. This decrease in white blood cell count was frequently found in aged patients or those with perforation of the large intestine. In these patients decreased white blood cell count increased soon after operation.

The mortality of leukocytopenia-associated patients was $12.5 \%$ without significant difference from that of no-leukocytopenia patients. However, in 11 patients concomitantly associating with hypotension on admission, the mortality was $27.3 \%$ versus null in 13 without hypotension. In the treatment operative procedure with less surgical invasion was selected, and postoperatively gamma-globulin preparations, plasma multi-enzyme inhibitors, H2: blockers were combinedly used. Leukocytopenia is reportedly a severe condition but appropriate treatment can save a life of such a fetal patient. 